\title{
AC 2009-717: CHILDREN'S CONCEPTIONS AND CRITICAL ANALYSIS OF TECHNOLOGY BEFORE AND AFTER PARTICIPATING IN AN INFORMAL ENGINEERING CLUB
}

\section{Pamela Lottero-Perdue, Towson State University}

Dr. Pamela S. Lottero-Perdue is an Assistant Professor of Science Education in the Department of Physics, Astronomy \& Geosciences at Towson University. She began her career as process engineer, taught high school physics and pre-engineering, wrote curriculum and was a master teacher for Project Lead the Way, and led two Project FIRST robotics teams. As a science teacher educator, she has added engineering content and pedagogy to her science methods courses for prospective elementary teachers. She teaches engineering to children in informal settings and studies the ways in which the children do so critically, and has recently partnered with a school district to implement engineering instruction in elementary schools using Engineering is Elementary units of instruction. 


\title{
Children's Conceptions and Critical Analysis of Technology Before and After Participating in an Informal Engineering Club
}

\begin{abstract}
This mixed-methods study examines the way in which elementary-aged children participating in an informal engineering club and using Engineering is Elementary (EiE) curricula define technology and critically analyze how technologies may be beneficial or detrimental to people or the environment. Definitions of technology were measured using pre-post assessments, and further investigated through intensive pre-post interviews. Interviews also queried children about how they critically analyze technology. Consistent with larger studies of EiE assessment results, this study suggests that prior to exposure to the EiE curriculum, children had formed relatively narrow conceptions of what counts as technology. After participating in the club, most children's conceptions of technology broadened. Both before and after club participation, children were able to elicit ways in which technology was beneficial or detrimental, yet the responses of some children were more elaborate than others. Interview data allude to the importance of concrete examples of technology as students reconstruct definitions of technology and consider how technology may be beneficial or detrimental to people and the environment.
\end{abstract}

\section{Introduction}

This paper seeks to answer two questions about a group of 23 elementary-aged children before and after their participation in a summer engineering and science club (SEAS Club) that utilized Engineering is Elementary (EiE) curricula:

1. How do these children define and describe technology?

2. How do they critically analyze technology, that is, conceive of ways that technology may be beneficial or detrimental to people or the environment?

The background section of this paper addresses each of these big ideas-how technology is defined and the critical analysis of technology - in turn, and is followed by a description of the SEAS Club context and study methods. The findings for the first and second questions are presented thereafter and followed by a short discussion.

\section{Background}

\section{What is Technology?}

One goal of STEM education - that is, education related to science, technology, engineering, and math - is to develop technological literacy in children. ${ }^{1-3}$ Although there are varying definitions of what it means to be technologically literate, a necessary starting point is to consider what counts as technology and why. ${ }^{4,5}$ Other aspects of technological literacy-including how people might interact with, design, or critically analyze technology-follow this definitional understanding. 
In the colloquial and educational speech of our society, technology is often associated with computers, ${ }^{4,6}$ electricity, ${ }^{5,7}$ or an arm of vocational education. ${ }^{8}$ However, broader notions of technology are evident when technological development is cast in a timescale that reaches much further back than the advent of electricity, and when technology is considered to be a result of human problem solving. Cajas described technology not only as an item or artifact, but also as a form of knowledge and social practice, and referenced the broad notion of technology espoused by AAAS:

We use technology to try to change the world to suit us better. The changes may relate to survival needs such as food, shelter, or defense, or they may relate to human aspirations such as knowledge, art, or control. ${ }^{3}$

Similarly, Beneson suggested that technology included a "wide range of artifacts, systems, environments, and procedures that have been created by people to address their needs". 8

Technology, offered Beneson, included not only the computer-a complex device whose inner workings may be incomprehensible to the everyday citizen — but the box in which it came, a simple technology whose design is more accessible to laypersons.

Elementary-level engineering and technology curricula like The City Technology Curriculum and Engineering is Elementary (EiE) aim to help children see boxes and other everyday items as technologies that have purpose in their design and creation. ${ }^{5,7,8}$ The EiE curriculum encourages the following insights about technology:

- Anything that people design to solve a problem is technology.

- Technology doesn't always use electricity.

- People design technology.

- Anyone can design technology.

- Technology can be made of lots of different materials.

- Some kinds of materials (like plastic) are examples of technology.

- An engineer's job is to design technology.

EiE developers hope that children come to these insights through engagement in a one-hour preparatory lesson about technology and reinforcement in ten-hour units of instruction focused on an engineering field and the design of a specific technology. The preparatory lesson involves students exploring technologies such as toothbrushes, hair clips, or an eraser, and answering questions about what the object does, the problem it solves, and the materials of which it is made. The engineering units each have four lessons, beginning with a story about a child who uses the engineering design process to design a technology and ending with the students similarly engaging in technological design.

EiE project leaders have developed pre-post assessments to measure students' knowledge of engineering and technology. The multi-part question about technology presents 16 different items in a $4 \times 4$ grid, each having a clip-art-like picture and a label, and asks students to circle those items that are technology. Items were selected to create a range from easy-to-identify technologies (e.g., power lines) and non-technologies (e.g., dandelion) to difficult-to-identify technologies (e.g., shoe) and non-technologies (e.g., lightening) (see Table 1). ${ }^{7}$ This multi-item 
question was followed by the following open-ended response question: "How do you know if something is technology?"

Table 1: Degree of difficulty for items on the EiE assessment for "What is technology?"

\begin{tabular}{|c|l|}
\hline Degree of difficulty & Items and Status as Technology or Non-Technology \\
\hline High & Cup, Bandage, Books, Shoes (technologies) \\
\hline Moderate & $\begin{array}{l}\text { Bicycle, Bridge, House, Factory (technologies) } \\
\text { Lightening (non-technology) }\end{array}$ \\
\hline Low & $\begin{array}{l}\text { Subway, television, cell phone, power lines (technologies) } \\
\text { Oak tree, dandelions, bird (non-technologies) }\end{array}$ \\
\hline
\end{tabular}

Studies conducted by EiE leaders provide information with regard to children's conceptions about technology prior to and after EiE instruction. A 2005 study used a random sample of 504 elementary-aged students in a school district in Massachusetts. ${ }^{5}$ The results revealed that children most often correctly identified electrical technologies, namely: television $(89.2 \%$ of children responded correctly), cell phone (87.4\%), power lines $(81.0 \%)$, subway $(73.7 \%)$, and factory $(58.1 \%)$. They also tended to correctly exclude three objects that are not technologies: parrot $(96.2 \%)$, dandelion $(95.2 \%)$, and oak tree $(94.6 \%)$. The other and more difficult items ranged in correct response from cup (8\%) to lightening $(65.9 \%)$. Written responses to the openended question included, in order of frequency: that technology has/uses electricity; that they (students) are smart, which is how they know what to include as technology; examples of how a technology could be used; and that technology is made by people.

A 2007 study conducted by EiE leaders showed promising results regarding the strength of the curriculum to broaden students' understandings of technology. ${ }^{7}$ The study was conducted across 7 states and involved a sample size of 5,139 students who used the EiE curriculum and 1,827 'control' students who were not exposed to EiE. The EiE sample improved significantly more on the post-assessment in their ability to correctly identify technology (and, thus, to identify nontechnology) when compared to the control. Post-assessment scores for the EiE sample were significantly improved from pre-assessment scores for the nine items classified as "high" or "moderate" level of difficulty (see Table 1).

\section{Critical Analysis of Technology}

In Rose's investigation of how STEM leaders perceive of technological literacy, she offered that even in its earliest conceptions, technological literacy "embodied the knowledge and skills needed to function in a society dominated by technological innovation and its impact upon society". It is the lattermost element-impact upon society, and by extension, environmentthat makes technology, like any other human construction, a legitimate subject of critique.

Science, Technology, Society (STS) curricula have been developed and implemented to encourage students to investigate the complex interactions between the world and the artifacts and knowledge that humans construct. ${ }^{10}$ These typically theme-based curricula have collectively 
helped children to take critical stances with respect to technology, that is, to consider the ways in which technology may be both helpful and detrimental to people and the larger environment.

Another approach educators can take to encourage children to critically analyze technology comes from the 'critical text analysis' (CTA) and 'critical literacy' traditions in literacy (i.e., reading/writing) education. ${ }^{11}$ Advocates of CTA assert that it is imperative for individuals of all ages to not only decode what they read, comprehend what they read, and consider text use and their purpose for reading, but also to ask questions about text positioning, i.e., to ask:

- How does this text position me, others, or reality?

- Does this text include or ignore my or others' voice(s)?

- In whose interests has this text been written? ${ }^{12}$

For example, elementary children have examined advertisements sent around Mother's Day, and considered how these texts: suggest that mothers want certain things; exclude what some mothers may really want; presume that children may have significant money to spend on Mother's Day; and are fundamentally interested in a sale, rather than in reinforcing a motherchild bond. ${ }^{13}$

Although CTA advocates often consider written texts as artifacts of critical analysis, their use of the word, 'text', actually extends much farther to include that which is seen, gestured, or spoken. ${ }^{14,15}$ Thus, television advertisements, pictures, and radio broadcasts are apt subjects for critical analysis. ${ }^{16}$ Furthermore, scientific texts of written and multi-media form have been the subjects of critical text analysis research. ${ }^{17,18}$

Technologies are human constructions that are likewise apt for the kinds of critical questions posed above. ${ }^{19}$ In this way, technologies are texts that warrant critical analysis. Reframing the earlier questions, we ask about technology:

- How does this technology position me, others, or reality?

- Does this technology include or ignore my or others' voice(s)?

- In whose interests has this technology been designed?

Recall the earlier AAAS quote about technology as being used to "change the world to suit us better" for survival needs, or for human aspirations. ${ }^{3}$ The above critical questions urge us to ask: Who is "us" and who may be 'not us'? Whose survival or aspirations are included here, and whose may be left out?

The strength of this approach is that it may be applied to existing or imagined technologies. Children interacting with technologies in the course of engaging with $\mathrm{EiE}$ or other engineering or technology curricula may be guided to give pause to consider the opportunities and challenges that technologies create. They might consider, for example, that the convenience of an everyday item such as a plastic bag negatively impacts the environment, that the color of a bandage can exclude people of color from the privilege of an inconspicuous wound, or that even wind turbines have downsides. 
There are challenges to and much to be learned about this approach. First, it adds a degree of complexity to the notion that technology is the solution to a problem, inspiring the questions: Whose problem are we solving?; Who does not have this problem?; and What other problems might the technology potentially create? Second, there are few models in the literature that exemplify what instruction that encourages this kind of critical technological literacy looks like. Third, and a matter addressed in part by this paper, we know little about how children are critical of technology as a result of their experiences in the world. To know this is to know upon what we are building as we encourage critical approaches to technology among children in schools and in informal learning environments like the SEAS Club.

\section{Context}

\section{Original Participants}

The SEAS Club initially involved 23 children who were participating in a 6-week long summer program at a local Boys \& Girls Club (BGC). The SEAS Club was divided into two groups: 1) a younger group for children entering $1^{\text {st }}$ or $2^{\text {nd }}$ grade the following year; and 2) an older group for those entering $3^{\text {rd }}$ through $5^{\text {th }}$ grades (the 'older' club). There were 76 BGC summer program attendees who were eligible to participate in the club. Of these, $21(\sim 28 \%)$ provided signed forms indicating interest and parental permission to participate. In addition, two childrenentering the $6^{\text {th }}$ and $7^{\text {th }}$ grades, respectively-returned forms. All 23 children who submitted forms were allowed to participate.

Of the 23 original participants, 7 (30\%) were female, which is consistent with the population of BGC summer program attendees (32\% female). Also reflective of this population is the ethnic diversity in the SEAS Club: 8 members of the SEAS Club (35\%) were African American; 2 (9\%) were Hispanic; and $13(56 \%)$ were white. SEAS Club participants were not asked about their socioeconomic (SES) status, however, according to a BGC leader, the SEAS Club and BGC summer program participants had SES levels ranging from low- to mid-level.

SEAS Club participants were not asked to divulge report cards or grades. Anecdotal evidence revealed that there was a wide range in scholastic achievement among the participants, and many children described themselves as having great difficulty with reading and writing.

\section{Club Activities}

Club activities were centered on EiE units of instruction enhanced by trade book read-alouds and field trips. The younger group, having 9 participants, met for 5 sessions, spending 10 hours on the "Civil Engineering: Designing Bridges" unit, which included the preparatory lesson about technology. The older group, which began with 14 participants, met for 12 sessions over a total of 24 hours. Like the younger group, the older children began the SEAS club with the preparatory lesson on technology, and then engaged with two units in succession: "Agricultural Engineering: Designing Hand Pollinators"; and "Mechanical Engineering: Designing Windmills." 
Supplementary trade books complemented each unit to encourage critical thinking about the social and environmental consequences of technology. These were read aloud to students throughout the SEAS Club. ${ }^{i}$ For example, the younger children read Pop's Bridge and Brooklyn Bridge ${ }^{20,21}$ which both reinforced the idea that bridges are essential and elegant technologies, yet can be difficult and dangerous to build. The book, Generating Wind Power, ${ }^{22}$ addressed both the benefits of wind power as an alternative energy source, and the challenges and drawbacks of this technology.

There were two field trips. The older group went to a local community college for an outdoor tour of a small wind turbine that is used to generate power for a pump to aerate a pond. At the end of the program, the entire SEAS Club went on a two-hour skipjack sailboat ride to explore the properties of sails and to sail by and investigate a local bridge.

\section{SEAS Club: Like School and Not Like School}

Especially as this study references larger studies about students' understanding of technology as measured in school environments, it is important to address some of the ways in which the SEAS Club was similar to and different from EiE unit implementation in schools. Like these school environments, the SEAS Club met in a classroom-like environment, the overall lesson format of EiE curricular materials was followed, and the SEAS children had a 'teacher' - the author of this paper-and often, an assistant teacher, who helped.

Despite these schoolish ways of operating a summer club, the SEAS Club was quite unlike school in the following ways:

1. It was not compulsory. Children were free to stop attending the club at any time, as stipulated on the permission forms, and did not need parental permission to quit.

2. It 'competed' with the games room and time spent in the gym. The classroom looked out onto the games room, an area in which other children were playing board games, pool, ping-pong and other games while the SEAS Club was running. Furthermore, children were pulled out of activities like the games room and gym to attend the club sessions. Although they had many hours each week to play games and play in the gym, even the most engaged of SEAS children were disappointed to be removed from these other activities, only if it was once or twice a week.

3. The age range in each group was relatively wide. This was especially true for the older group. The multi-age setting presented opportunities for younger children to learn from older children, yet may have had negative consequences including disinterest among older children in the group to spend time with younger peers.

4. A separate science unit was not taught to SEAS participants prior to introducing the EiE unit. EiE is intended to be used either in tandem with or integrated into a unit of science instruction, with pre-post assessments begin given before and after the science-EiE pair, respectively. No separate science unit was taught in the SEAS Club.

5. The EiE curriculum was not exhaustively implemented. The number of worksheets that students were asked to complete was relatively small compared to worksheets provided in the EiE curriculum. The completion of worksheets generally resulted in a reduction of student interest (thus potentially creating motivation to leave the club). 
6. Attendance was 'spotty' due to summer vacations and other issues.

The list of ways in which SEAS was unlike school begins with "it was not compulsory." Within the first two weeks of the six-week program, two children from the older group dropped out. Each child independently shared that s/he was not interested in learning about engineering or science, and was unaware that a parent had signed her/him up for the SEAS Club. Two other children dropped out of the older group midway through the club. These girls were cousins, both entering the $5^{\text {th }}$ grade. Citing reasons of disinterest similar to the others who left, they strongly desired to be playing with peers in the games room rather than participating in the SEAS Club. All four children who left the SEAS Club were African American, and three of the four were girls. ${ }^{\text {ii }}$

As mentioned in the previous section, attendance was 'spotty.' Table 2, below, summarizes attendance including and excluding the four children who dropped out of the club. Percent of instruction that children attended was used since the older group had twice as many sessions as the younger group.

Table 2: Attendance of SEAS Club participants.

\begin{tabular}{|c|c|c|}
\hline $\begin{array}{c}\text { Percent of Club } \\
\text { Sessions Attended }\end{array}$ & $\begin{array}{c}\text { Number of Original 23 } \\
\text { Participants }\end{array}$ & $\begin{array}{c}\text { Number of 19 Participants } \\
\text { (Excludes those who Dropped Out) }\end{array}$ \\
\hline $80 \%-100 \%$ & 9 & 9 \\
\hline $60 \%-79 \%$ & 5 & 5 \\
\hline $40 \%-59 \%$ & 7 & 5 \\
\hline $0-39 \%$ & 2 & 0 \\
\hline
\end{tabular}

\section{Methods}

This mixed-methods study included both quantitative and qualitative data collection and analysis. The author was a participant-observer, conducting research and teaching the SEAS Club. Methods for data collection and analysis are discussed below.

\section{Data Collection}

Prior to the first SEAS Club session, participants completed the EiE Engineering \& Technology assessment, including the aforementioned multi-part question that asks children to identify technologies, followed by the open-ended question: "How do you know if something is technology?" Identical to this pre-assessment was a post-assessment given on the last day of the SEAS Club. All 23 original participants completed the pre-assessment, yet only 18 postassessments were completed. One child was absent on the day of the post-assessment, another child's assessment was misplaced, and three of the children who dropped out from the club did not complete a post-assessment. One of the children who dropped out and who had attended 6 of 12 sessions completed the post assessment. 
All but one of the original 23 children participated in a 25 minute-long, semi-structured, audiorecorded interview after taking the survey and prior to the first SEAS Club session. ${ }^{23}$ The child who did not participate was ill and unable to be interviewed prior to starting. There were three major sections of this pre-interview that are pertinent to the present study:

1) Questions that ask children to explain their answers to the technology questions on the pre-assessment (e.g., Can you tell me more about why you chose these things?);

2) Questions regarding whether and how technology is good or bad for people or the environment (e.g., "Do you think the things you chose as technologies are good for people? Why or why not?); and

3) Widget questions.

The third pre-interview section requires some explanation. A widget is a way of identifying an object or a device without name. The widget used in this interview was constructed by combining two automotive repair tools that have nothing to do with one another-a flywheel lock and stud extractor (Figure 1). They were selected because they were likely to be unfamiliar to children (and most adults) independently and especially in combination. The purpose of this was to have a completely novel technology whose use was indeterminate. Like the second major section of the interview, the interview questions regarding the widget aimed to explore children's critical analysis of a technology, albeit in an abstract way. After handing the widget to the child and telling him/her that "an engineer designed this widget" and that "this widget is a technology," the child was asked: 1) "Is it a good widget or bad widget? How do you know?"; and 2) "What kinds of questions would you ask to find out if this widget is good or bad for people or the environment?"

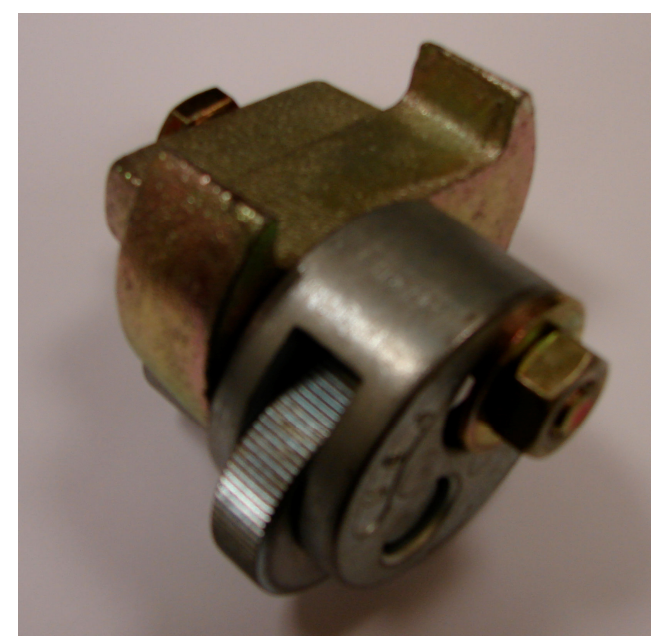

Figure 1. Widget

Post-interviews were conducted throughout the weeks and months following the end of the SEAS Club. Of the 23 original children, 18 participated in post-interviews; the four children who dropped out did not participate, and one child moved away and could not be reached for an interview. Like the pre-interviews, the post-interviews were roughly 25 minutes in length, semistructured in form, and audio-recorded. Post interviews began by asking the children: "What did you learn about technology in the SEAS Club?" Children were then shown a blank post- 
assessment and asked, "What counts as technology on this page?" They were asked if technology was good or bad for people or the environment, and the aforementioned widget questions were asked.

In addition to pre-post assessments and pre-post interviews, which comprised the bulk of data used in data analysis, student work was collected, and every SEAS Club session was audio- and video-recorded.

\section{Data Analysis}

Pre-post assessment data were entered into Excel ${ }^{\circledR}$ spreadsheets. Since only 18 participants had both pre- and post-assessment data, this subset of participants was used when calculating descriptive statistics. Overall pre- and post-assessment scores were generated for each child, and the average pre-assessment score for all SEAS Club participants was compared to the average post-assessment score using a two-tailed t-test.

Correct responses on pre- and post-assessments for each technology or non-technology on the $4 \times 4$ grid were compared, and a sign test was used to test whether or not pre-post differences were significant for each technology/non-technology. Previous work used the McNemar test to determine the statistical significance of improvements from pre- to post-assessment. ${ }^{7}$ The McNemar test, however, is not recommended for sample sizes smaller than 20, which is the case for the SEAS club ( $N=18$ pre-post matched assessment pairs). Although not deemed a powerful statistic, the sign test calculates probability (p) values that randomly chosen children would improve in their correct identification of technology if they attended the SEAS club.

Audio files from pre-post interviews were transcribed. Qualitative data analysis that ensued employed a grounded theory approach, which involved iterative reviews of the transcripts to search for recurrent themes. ${ }^{24,25}$ Using a combination of the qualitative analysis software, HyperResearch $^{\circledR}$, and Excel ${ }^{\circledR}$, the data were coded for major themes and then re-coded more finely for sub-themes to capture the range and frequency of participant response. Subcodes are described in the findings sections that follow, and cases and examples that help elaborate the subcodes and range of response were generated for the purpose of this paper.

\section{Findings}

\section{What is Technology?}

\section{$\underline{\text { Assessment Results }}$}

The quantitative findings are based upon the subset of 18 SEAS Club children who submitted both pre- and post-assessments. Figure 2 depicts the percentage of these children who correctly circled objects that were technology or left unmarked those that were not technology for each item on the assessment. Both pre- and post-assessment percentages are provided.

As expected based upon prior work, ${ }^{5,7}$ pre-assessments revealed that the SEAS club children performed better as the difficulty of items decreased (see Figure 2). For example, less than 5\% of 
children correctly identified the cup, bandage, or books as being examples of technology, while $100 \%$ of children correctly included power lines and excluded a dandelion and bird as examples of technology.

Post-assessments followed a similar overall pattern, and suggested that the children collectively improved with respect to some items, and worsened with respect to others. The sign test revealed that pre-post differences were significant for $\mathrm{p}<0.05$ for two items only-bandage $(\mathrm{p}=0.008)$ and bicycle $(\mathrm{p}=0.039)$-representing positive growth in children's understanding that these items are examples of technology.

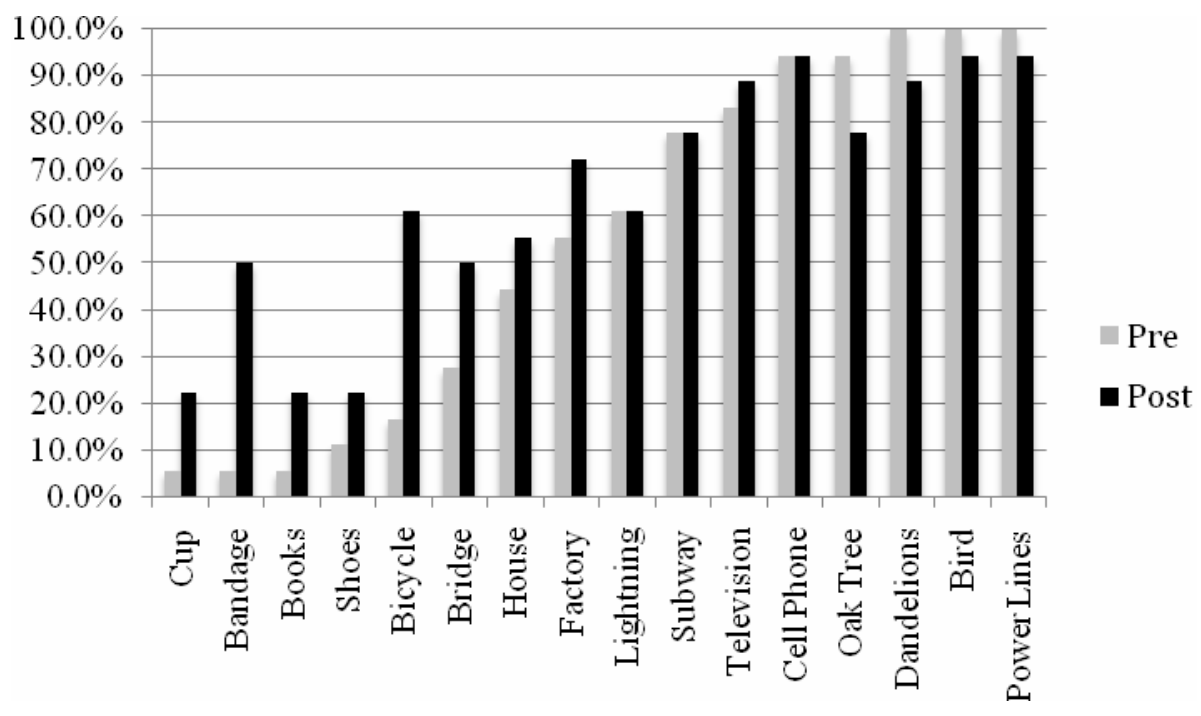

Figure 2. Percent of SEAS Participants Correctly Identifying object as Technology or NonTechnology $(n=18)$

Overall assessment scores for each child were calculated for pre- and post-assessments. The mean pre-assessment score was 8.8 correctly identified items out of $16(\mathrm{SD}=2.1)$, and the mean post-assessment score was $10.3(\mathrm{SD}=2.6)$. Although the difference in mean scores for pre- and post-assessments was modest, a two-tailed t-test revealed that it was significant $(\mathrm{p}=0.045)$.

The assessments provide a space in which children can answer the question: "How do you know if something is technology?" Consistent with findings for much larger samples of children, 5, SEAS Club children's pre-assessment responses often suggested that technology was necessarily electronic or involved the use of electricity, wires, or power; 14 of the original 23 children-over $60 \%$-included this aspect of technology in their responses. Four children provided other reasons, respectively offering that technology was: new (i.e., "not in the old days"); made by machines; "not made by the world"; and "works." Six children wrote an incomplete answer, indicated that they were not sure, or wrote "?" in response to the question.

Perhaps due to some combination of fatigue among the children and a lack of assistance proctoring the assessment, many children left the open-ended question on the post-assessments blank ( 7 of 18 children who took the post-assessment). ${ }^{\text {iii }}$ Two responses were unclear ("CUP" 
and "it involves it"). Two children maintained their pre-assessment responses, respectively offering that technology was "run on ELECTRICED [sic]" and "werks". Two children wrote that technology was "human made", and one offered: "technology is a solution to something you could do in the past." Other responses included that technology "can be fixed," "dose [sic] not stop", and helps if you need to go somewhere.

\section{Interview Results}

The pre-post assessments provide a snapshot in two points of time of how children identify and define technology. Interviews allowed students to elaborate their assessment choices and written responses verbally, and enabled the author to follow up to clarify these responses. Table 3 summarizes the defining features of technology identified by the percentage of SEAS club children responding to pre- or post-interviews. These defining features were identified via qualitative data analysis and represent subcodes from this process.

Beyond this table are descriptions of four cases_-of Amelia, Cady, Daniel, and Zachary—-that respectively describe the development of four children's ideas about technology. These cases represent differing degrees of change from pre- to post-interview. This is followed by a discussion of three themes that were highlighted by the interviews: 1) the tentative nature of some responses; 2) changes made to the pre-assessment during the pre-interview; and 3) specific examples from club experiences that were used in post-interviews to articulate views of technology.

Table 3: Summary of Pre-Post Interview Responses: What is Technology?

\begin{tabular}{|c|c|c|}
\hline $\begin{array}{c}\text { Defining Feature of Technology } \\
(* \text { indicates desirable response })\end{array}$ & $\begin{array}{l}\text { Pre-Interview } \\
\quad(\mathrm{N}=22)\end{array}$ & $\begin{array}{l}\text { Post-Interview } \\
\qquad(\mathrm{N}=18)\end{array}$ \\
\hline $\begin{array}{l}\text { Technology is electronic or has/uses } \\
\text { electricity, power, and wires. }\end{array}$ & $\begin{array}{c}86 \% \\
\text { (19 children) }\end{array}$ & $\begin{array}{c}28 \% \\
\text { (5 children) }\end{array}$ \\
\hline It is technology if it includes light. & $\begin{array}{c}18 \% \\
\text { (4 children) }\end{array}$ & $\begin{array}{c}6 \% \\
(1 \text { child })\end{array}$ \\
\hline Technology does not just sit there. & $0 \%$ & $\begin{array}{c}17 \% \\
\text { (3 children) }\end{array}$ \\
\hline $\begin{array}{l}\text { Technology is made of certain kinds of } \\
\text { materials. }\end{array}$ & $\begin{array}{c}14 \% \\
\text { (3 children) }\end{array}$ & $\begin{array}{c}11 \% \\
(2 \text { children })\end{array}$ \\
\hline Technology is new. & $\begin{array}{c}4 \% \\
(1 \text { child })\end{array}$ & $0 \%$ \\
\hline Technology is made by humans.* & $\begin{array}{c}14 \% \\
\text { (3 children) }\end{array}$ & $\begin{array}{c}28 \% \\
\text { ( } 5 \text { children) }\end{array}$ \\
\hline Technology helps humans do things.* & $\begin{array}{c}23 \% \\
\text { (5 children) }\end{array}$ & $\begin{array}{c}78 \% \\
\text { (14 children) }\end{array}$ \\
\hline
\end{tabular}




\section{Amelia}

Amelia was entering the $3^{\text {rd }}$ grade the following year, and missed about half of SEAS Club instruction. She was, however, present for the preparatory unit about technology after which the children in the older SEAS club shared the following "new" ideas about technology:

- something that solves a problem

- $\quad$ some are natural and some are human made (materials) [e.g., a technology made of wood]

- does not have to be wires, power, batteries

- examples: tape, pencil, subway, marker, binder, chair, camera, and bowl

Additional examples were added on the following session, including: car, pen, paper, dirt bike, television, camera phone, projector, and laser pen. Two weeks later, more examples included: table, glue, clock, cup, hand pollinator, integrated pest management, and pesticides.

On Amelia's pre-assessment, she indicated that the only technologies were the subway, cell phone, television, and power lines. Although her written explanation on the assessment was incomplete, in her pre-interview she shared that the items she selected were technologies because they had wires. In her post-assessment, Amelia re-selected her pre-assessment choices, and added lightening as another technology. Her written reason for these choices was "It dose [sic] not stop." The post-interview revealed that Amelia may be beginning to understand that technology is helpful, yet seems to maintain the idea that it must also involve electricity:

Pam: $\quad$ Alright. So what is technology?

Amelia: $\quad$ Technology is something, like, if you can't see in the dark, like, light is technology.

A few moments later, she suggested another defining feature of technology: that it must be active.

Pam: ... $\quad$ So what about a cup? Is a cup technology?

Amelia: $\quad$ No.

Pam: $\quad$ No? And what about - why isn't a cup technology? Tell me why.

Amelia: $\quad$ Because it doesn't work, like a phone or like a subway. It doesn't do anything.

Although her choice of lightening as a technology was not discussed in the post-interview, perhaps its active nature, coupled with its association with electricity, caused her to think of it as technology.

\section{Cady}

Cady was in the younger group, entering the $2^{\text {nd }}$ grade the following year. She attended all of the sessions of the SEAS Club, including a preparatory lesson and reinforcement similar to what occurred in the older club, described above. In her pre-assessment, she identified the following 
as technologies: subway, cell phone, television, factory, house, power lines, lightening. Her written reasoning was: "I now [sic] if something is technology or not a house is technology because the light switches! Phone charchers [sic] too." Cady maintained this view of technology in the pre-interview, offering that her selections were technologies because "they're electric and they use light." In the post-assessment, she added the following technologies: bridge and bicycle. She had spent the summer studying bridges, reinforced through teaching as being a "technology."

Cady did not provide a written response regarding her post-assessment choices, yet the growth in her conceptual understanding of what constitutes technology is evident in the post-interview. Cady had trouble providing an overarching statement about technology (e.g., as did Charles, who offered that "technology is anything that is human made" and that "it helps you do things"), yet she was able to provide multiple examples of technologies, many of which were introduced during instruction in the preparatory lesson. The interview began this way:

$\begin{array}{ll}\text { Pam: } & \text { What did you learn about technology in the SEAS Club? } \\ \text { Cady: } & \text { [I] didn't know that a toothbrush was technology. } \\ \text { Pam: } & \text {... how is a toothbrush technology? } \\ \text { Cady: } & \text {.. (silence } 4 \text { seconds) } \\ \text { Pam: } & \text { What does it do? } \\ \text { Cady: } & \text { Cleans your teeth. } \\ \text { Pam: } & \text { Yeah? And so what makes that technology? } \\ \text { Cady: } & \text { (silence } 18 \text { seconds) } \\ \text { Pam: } & \text { Is that a hard question to answer? } \\ \text { Cady: } & \text { (indicates yes) }\end{array}$

The toothbrush was one of the technologies used in the preparatory lesson, as was the cookie scope and floss that she mentioned in response to a follow-up question: "So what are some other examples of technology?" She was not sure what a cookie scoop was for, but described the teeth and gum cleaning benefits of floss.

When queried about whether or not objects on the blank assessment were technologies, Cady was clear that cell phones were technologies, and that bandages and cups were not. She was, however, somewhat tentative in her response to whether or not a bicycle, which she identified as a technology on the post-assessment, was a technology:

$\begin{array}{ll}\text { Pam: } & \text {.. Would a bicycle be a technology? } \\ \text { Cady: } & \text { I think. I don't know. } \\ \text { Pam: } & \text { You think so? What could a bicycle help you do? } \\ \text { Cady: } & \text { Balance. }\end{array}$

Her argument that bandages and cups were not technologies used the same active requirement for technology as was evident in Amelia's post-interview:

Pam: How about a Band-Aid or bandage?

Cady: $\quad$ No. 
Pam: $\quad$ No? That wouldn't be technology? Why not?

Cady: $\quad$ Because it just makes, it doesn't - it just makes /no germs get on your scratches ... and scrapes.

Interestingly, this logic — and not an argument regarding human design—was also applied to argue that trees are not technologies.

\section{Daniel}

Daniel was an example of a SEAS Club participant who demonstrated great growth towards desired ideas about technology. He was entering the $3^{\text {rd }}$ grade after the SEAS Club summer, and although he missed four days of the club, was present for the aforementioned preparatory lesson on technology. Like Amelia and Cady, his pre-assessment responses largely reflected the first subcode in Table 2: Technology is electronic or has/uses electricity, power, and wires. He selected cell phone, factory, television, and power lines as technology, explaining in writing that "technology is something that is made by machines or something [that] takes different types of power." In his pre-interview, he elaborated this idea:

Pam: $\quad$... Can you tell me a little bit more about why you chose those things? Daniel: $\quad$ I chose them because some of them - technology takes certain types of powers and anything that usually takes, like, something - somebody that invented that takes - and you use, like, pliers, you use alligator clips - I know a lot of them types of wires. You might even use / what's it called again? Copper wire!

He spontaneously offered that lightening is "just something that happens on Earth," which is why he did not select it, and also reconsidered his choice of subway as a technology without a clear reason. Finally, he alluded to a connection between technology and digital electronics, explaining that television is technology because "you need the little tiny particles to, like, form up with multiplication and division" and that somehow, "simple math" was involved.

Daniel was the only child to receive $100 \%$ on the post-assessment, identifying all items correctly. He wrote that technology is "something that is human made." His post-interview elaborated on this response, and began with his recollection of the first example provided in the SEAS Club of a technology, a sticky note:

Pam: $\quad$ Alright. So what do you remember learning about technology in the SEAS Club?

Daniel: $\quad$ I remember that a stick note is technology.

Pam: $\quad$ A sticky note is technology? How come it's technology?

Daniel: $\quad$ Because you said that it's paper and they - they wanted to find a glue that's really, really sticky and they made a glue that is not sticky.

[discussion ensued about why a note that is not very sticky should be called a sticky note] 
Pam: $\quad$... So why is it - why do we call that technology? Why does that get to count as technology? It's just a note, right? What does it do that makes it technology?

Daniel: $\quad$ It - it helps people.

The final comment in the excerpt, above, pushes Daniel beyond his written observation that technology is human made, and gives technology a purpose - to help people.

\section{Zachary}

Zachary was in the younger SEAS Club group, and was entering the $2^{\text {nd }}$ grade the following year. He was present for all of the SEAS Club sessions. Zachary received the highest overall score on the pre-assessment of any of the SEAS Club children, correctly identifying 15 of 16 items as technologies or non-technologies. His single oversight was that he did not identify shoes as a technology. Zachary had great difficulty with writing, and his explanation on the preassessment was written verbatim for him by the author: "If didn't have subway, couldn't eat. Cell phone to talk to somebody. Help do things." In the pre-interview, Zachary provided further examples of how technology is helpful, e.g.: "if you didn't have a bridge, the cars wouldn't be able to go over ... if you didn't have a cup — with coffee in it—you would burn yourself with coffee." At a different point in the pre-interview and without prompting, Zachary paused and circled shoes on his pre-assessment.

Pam: $\quad$ So you just circled shoes.

Zachary: Yes.

Pam: $\quad$... So - you said - what do shoes help you do?

Zachary: Walk. And if you didn't have any shoes and you were walking on stones it would really hurt.

What is fascinating about Zachary is that his score on the post-assessment was lower by three items than his pre-assessment. Part of this was due to his exclusion of television and bicycle as technologies, and part was due to his addition of dandelion as a technology. His written explanation, again written for him by the author, was "technology is if you need to go somewhere and can't."

Zachary's focus on the helpful nature of technology was extended in the post-interview in which Zachary discussed the ways in which technologies like cell phones, bandages, and bridges help people. This, however, became an over-extended concept of technology as he went on to suggest that animals and people might also be technologies:

Zachary: And technology is animals, too, right? So a snake - a crocodile wanted a snake. It was hungry. And the snake, of course, was in the plants right in the water - a water snake? And the crocodile ate it. So that's good.

Pam: $\quad$ So can a - An animal can be technology?

Zachary: Yeah.

Pam: $\quad$ What makes them technology? Are all animals technology?

Zachary: Some. 


$\begin{array}{ll}\text { Pam: } & \text { Some? } \\ \text { Zachary: } & \text { Some are not. } \\ \text { Pam: } & \text { Yeah? } \\ \text { Zachary: } & \text { Well actually, yeah, actually all of them. } \\ \text { Pam: } & \text { And why would they be technology? } \\ \text { Zachary: } & \text { Because - gooey buggy! [Note: the interview took place outside. He saw } \\ & \text { some gnats.] I don't like them bugs! They're - they bite! } \\ \text { Pam: } & \text { They bite you. That's what bugs do. They do. } \\ \text { Zachary: } & \text { Yeah. So technology is when people try to help other people. } \\ \text { Pam: } & \text { Okay. Is it because animals can help other animals that they're - } \\ \text { Zachary: } & \text { Yeah! } \\ \text { Pam: } & \text { - technology? Is that what you're saying? } \\ \text { Zachary: } & \text { Yeah ... }\end{array}$

This over-extension of the helpful nature of technology was not evident in Zachary's postassessment, which only identified the dandelion — and not the tree or bird — as being technologies. Additionally, the assumption plants and animals can be helpful, and thus are technologies, was taken up by two other children who described trees as being technologies that are helpful shelters or oxygen producers.

Zachary did mention the television or bicycle as being technologies or non-technologies, and thus it is unclear why these were excluded on the post-assessment. Finally, Zachary briefly considered shoes as a technology and then withdrew this idea, but then quickly changed course in the interview before explaining this tentative consideration about shoes. Part of what may be at work with these inconsistencies is that Zachary was extremely distracted during the SEAS Club sessions, assessments, and interviews.

\section{Other Themes from the Interviews}

The cases of Amelia, Cady, Daniel, and Zachary highlight many of the conceptions of technology in Table 3. These cases also include elements of three additional themes worthy of note here. First, the children were often tentative about one or more of their selections on the assessments, which was made apparent in the interviews. Emily's ambivalence about the bicycle in the post-interview is one such example. Roughly $33 \%$ of the children who took part in the preinterview and $41 \%$ of those who participated in the post-interview indicated that they were still unsure about whether or not an item was technology. This suggests the tentative and developing nature of children's ideas.

Second and a related point, the assessments are instances in time on this developmental path, and a second chance to think and talk about the assessment—even without instructional intervention-may inspire new choices. About $18 \%$ of pre-interviewees requested that changes be made to their pre-assessments, typically to have more items identified as technologies. In Zachary's pre-interview, for example, he circled shoes.

Third, half of the children who participated in post-interviews recalled specific examples of technology from SEAS Club instructional experiences when asked to describe technologies. For 
example, toothbrushes and sticky notes-not cell phones or televisions-were the first technologies that Cady and Daniel respectively recalled. This suggests that the examples of technology used in the SEAS Club have great and lasting value.

\section{Critical Analysis of Technology Among SEAS Club Participants}

Interviews addressed children's critical analysis of technology via two means: 1) by asking if the technologies they chose (pre-interviews) or what they conceived of as technology (postinterviews) were good or bad for people or the environment; and 2) by asking the aforementioned widget questions. Results from these lines of questioning will be discussed in the sections that follow.

\section{Is Technology Good or Bad for People or the Environment?}

Both before and after the SEAS Club, well more than half of the SEAS Club children responded that technology was both good and bad for people and bad for the environment (Table 4). Somewhat fewer students-41\% in pre-interviews and $33 \%$ in post-interviews-responded that technology was somehow good for the environment. As reflections of trends within qualitative data, these percentages only provide a measure of relative frequency, and speak not to statistical difference.

Table 4: Summary of Pre-Post Interview Responses: Percent of Children who Indicated that Technology was Somehow Good or Bad for People or the Environment?

\begin{tabular}{|l|c|c|}
\hline \multicolumn{1}{|c|}{ Technology is somehow ... } & $\begin{array}{c}\text { Pre-Interview } \\
\text { (N=22) }\end{array}$ & $\begin{array}{c}\text { Post-Interview } \\
\text { (N=18) }\end{array}$ \\
\hline Good for people & $\begin{array}{c}95 \% \\
(21 \text { children })\end{array}$ & $\begin{array}{c}89 \% \\
(16 \text { children })\end{array}$ \\
\hline Bad for people & $\begin{array}{c}64 \% \\
(14 \text { children })\end{array}$ & $\begin{array}{c}72 \% \\
(13 \text { children })\end{array}$ \\
\hline Not sure if it's good for bad for people & $0 \%$ & $0 \%$ \\
\hline Good for the environment & $\begin{array}{c}41 \% \\
(9 \text { children })\end{array}$ & $\begin{array}{c}33 \% \\
(6 \text { children })\end{array}$ \\
\hline Bad for the environment & $\begin{array}{c}64 \% \\
(14 \text { children })\end{array}$ & $\begin{array}{c}67 \% \\
(12 \text { children })\end{array}$ \\
\hline $\begin{array}{l}\text { Not sure if it's good for bad for the } \\
\text { environment }\end{array}$ & $\begin{array}{c}18 \% \\
(4 \text { children })\end{array}$ & $(2$ children $)$ \\
\hline
\end{tabular}

What is more interesting is to examine the reasons that children provided regarding the benefits and detriments of technology. The nature of these reasons seemed to shift from pre- to post-interviews, largely due to a broadened conception of what counted as technology in the post-interviews. The range of reasons for why technology may be good for people, bad for 
people, good for the environment, and bad for the environment is explored in the four sections that follow.

\section{Good for People}

In both the pre- and post-interviews, children's reasons why technology was good for people largely spoke to the ways in which technology was helpful. Daniel shared that technology "helps you live better," and others provided such broad statements, as well. Other children used more specific examples. When Amelia responded affirmatively that technology was good for people, the following transpired:

Pam: $\quad$ Any reasons for that? Can you give me an example?

Amelia: $\quad$ Like sometimes on television, you can check the weather.

Pam: Okay.

Amelia: $\quad$ And power lines can help you call people, and subways help you travel to places like if you are going on vacation.

Such helpful examples reflected conceptions of what counts as technology-and for Amelia and many other children in the pre-interview, these things involved electricity. Examples of helpful items mentioned by children in pre-interviews included: bridges (included because they had electricity), televisions, power lines, subways/trains, house, lights, and cell phones.

Some children in the pre-interview (7 or 31\%) mentioned that technology helped to keep people safe or helped them survive:

Pam: Why are they [the items circled] good for people?

Javier: Because a house keeps you safe and // wires keep the light on in the city, and the train lights in front of it so it knows where it's going.

Cell phones were associated with safety, as well. For example, Mark offered that "they can help you communicate with other people, like if there's - like 9-1-1. If someone's really hurt."

Post interviews did not reflect issues of safety or survival, yet emphasized the helpful nature of technology to people, albeit using a somewhat broader range of technology than in preinterviews. Examples of helpful items in the post-interviews included: bridges, televisions, light, robots, cell phones, bandages, toothbrushes, and shoes.

\section{Bad for People}

The five most frequent reasons that children provided in pre- and post-interviews for why technology can be bad for people is summarized in Table 5. As was the pre-post shift in reasons for how technology can be good for people, as children moved away from a conception that technology necessarily involved electricity, their collective critical reasoning patterns changed.

The consequences of watching too much television in the pre-interviews were not mentioned at all in the post-interviews. In the pre-interview, for example, Charles offered that too much 
television might be bad for people because it "could give you a headache, or maybe you're lazy and you just don't want to move anywhere." Similarly, the problems that cell phones might cause - including getting in trouble for or straining one's eyes because of too much texting, or loosing one's phone and having personal information on it stolen-were not mentioned in postinterviews. In the pre-interviews, electrocution was mentioned as a consequence of human interaction with lightening or power lines, yet only one child mentioned electrocution in the postinterviews.

Table 5: Summary of Pre-Post Interview Responses: Top Five Reasons for How Technology is Bad for People

\begin{tabular}{|c|c|}
\hline $\begin{array}{l}\text { Pre-Interview Order of Reasons } \\
\text { (Percent/\# of } 22 \text { Children) }\end{array}$ & $\begin{array}{l}\text { Pre-Interview Order of Reasons } \\
\text { (Percent/\# of } 18 \text { Children) }\end{array}$ \\
\hline $\begin{array}{l}\text { Too much television is bad for people's } \\
\text { brains. ( } 32 \% ; 7 \text { children) }\end{array}$ & $\begin{array}{l}\text { People can be physically injured by } \\
\text { technologies. (39\%; } 7 \text { children) }\end{array}$ \\
\hline $\begin{array}{l}\text { Cell phones can get people in trouble and } \\
\text { cause other problems. ( } 27 \% ; 6 \text { children) }\end{array}$ & $\begin{array}{c}\text { People can breathe in nasty fumes, } \\
\text { smoke, or polluted air. (11\%; } 2 \text { children) }\end{array}$ \\
\hline $\begin{array}{l}\text { People can be electrocuted. (18\%; } 4 \\
\text { children) }\end{array}$ & $\begin{array}{c}\text { Technology can be bad for people, but not } \\
\text { sure why. (11\%; } 2 \text { children })\end{array}$ \\
\hline $\begin{array}{l}\text { People can breathe in nasty fumes, } \\
\text { smoke, or polluted air. (5\%; } 1 \text { child) }\end{array}$ & People can be electrocuted. $(6 \% ; 1$ child $))$ \\
\hline $\begin{array}{l}\text { People can be physically injured by } \\
\text { technologies. }(5 \% ; 1 \text { child })\end{array}$ & $\begin{array}{c}\text { New technology can "act up". (6\%; } 1 \\
\text { child) }\end{array}$ \\
\hline
\end{tabular}

Post interviews reflected an emphasis on physical injuries that may be caused by technologies, including that babies might be injured by playing with wires or a pencil, people could be harmed if they were wearing poorly fitting shoes, or that people could be harmed if something went wrong as a machine was being tested.

Two additional examples regarding bodily harm from the post-interviews are worthy of note. Zachary used examples from one of the trade books read in his younger SEAS Club group, The Brooklyn Bridge, ${ }^{21}$ to articulate how technology can be bad for people:

Pam: Is there any way that technology could be bad for people or bad for the environment?

Zachary: $\quad$ Yeah, because, like, you said, in this book ... what book was that? ...

Zachary proceed to flip through the book with great speed, recalling the ways in which building the bridge was dangerous for people who worked on it. Zachary recalled how John Roebling, the engineer who designed the bridge, suffered fatal injuries when a ferry boat crushed his leg (by a boat). He also talked about the workers who died in the caissons, and how others died working on the cables. 
Finally, one conversation in a post-interview highlighted a different kind of bodily harm, and a new idea about what counts as technology. Although not a focus of this paper, part of the postinterview involved parental input. During Jordan's post-interview, both of his parents were present and seemed extremely interested in even the questions directed at Jordan. The following transpired regarding the topic of smoking and cigarettes:

Pam: ... $\quad$ So can you let me know if there's any way that technology could be bad for people or the environment?

Jordan: Gas coming out of the car.

Pam: $\quad$ Oh, you think gas -

Jordan: $\quad$ And smoke.

Pam: $\quad-$ is that bad for people, or the environment, or both?

Jordan: $\quad$ Both.

Pam: $\quad$ Both?

Jordan: $\quad$ Because we can - breathe in and we might die.

Pam: $\quad$ Okay.

Jordan: $\quad$ Like I do all the time. (Directed at mother.)

Pam: (Who missed the comment Jordan just made.) Are there any other ways that technology might be bad for people or the environment?

Mom: $\quad$ Smoking.

Jordan. Yes, smoking.

Pam: $\quad$ Smoking.

Jordan. I've got a bad cough. I'm glad my mom quit.

Pam: Well that's good. Congratulations. Well smoking can be - Is a cigarette a technology?

Mom: $\quad$ I think so because it's made by man, and man has to use the machines which is electric, which is technology for them to build it, for them to make it.

Jordan: $\quad$ Yeah.

Pam: $\quad$ Okay.

Mom: $\quad$ I could be wrong, but.

Pam: $\quad$ Yeah. But that's how you're thinking a cigarette could be a form of -

Mom: $\quad$ Because it's all manufactured. And a factory's all electricity and it's all electric.

There are many interesting elements of this exchange, including a mother and son's codevelopment of an understanding of cigarette as a technology, which they have agreed long prior to the interview is bad for people, in general, and them, in particular. Additionally, Jordan articulates another category of reasoning — used by other children, as well—that gas, smoke, and fumes emitted by technologies are bad for people.

\section{Good for Environment}

Overall, children seemed to be less sure about the impact of technology on the environment than about the impact on people (Table 4). In pre-interviews, the most common reason for why 
technology was good for the environment was "not sure" (50\% or 11 children in preinterviewees). Two children (10\%), Jordan and Cady, shared ideas in pre-interviews. Cady suggested that technologies that are inside houses are out of range of potential harm for animals, and thus, they are good for the environment (e.g., "a cell phone is inside, so they can't get anywhere close to that"). She furthermore offered that houses, which are technologies, are places where "birds make their nests and they don't get rained on." Jordan's idea that trees are technologies enabled him to describe a benefit of trees to the environment: that "birds can have a nest in the oak tree." In both of these cases, the children conceived of the environment by thinking about animals. In the interview protocol, "environment" was described as "animals and the planet."iv

In post-interviews, fewer children (22\% of those interviewed, or 4 children) shared that they were unsure about why technology was good for the environment. Four children provided reasons regarding the benefit of technology to the environment. Jordan re-expressed his preinterview idea that trees were technologies, and thus good for the environment as shelters for animals. Likewise, Andrew shared that trees "give oxygen," and thus are good technologies for the environment.

Two additional examples of the benefits were provided, one of which came from a field trip experience in the SEAS Club to visit a wind turbine:

Pam: ... $\quad$ You said that sometimes technology is good for the environment. How's that? Can you give me an example?

Jack: $\quad$ Because - some people use technologies to fix things. And - some people use technologies for the water, too, like - like at that one windmill thing we went to.

Pam: $\quad$ The wind mill thing. Uh huh (yes).

Jack. And - they said they had a - because all the algae and stuff - that had that one pump that blew air into it.

In this case, the wind turbine generated power to support a pump to provide oxygen to the pond-an excellent example of an environmentally friendly technology. Although Jack recognized the ultimate purpose for the wind turbine, he did not comment that this technology was fueled by a renewable resource.

The other example was provided by Daniel was an imagined air-cleaning technology:

Pam: Is technology good for the environment?

Jack: $\quad$ Some of it yes. Some of it no.

Pam: $\quad$ Explain, please.

Jack: Which one? Yes or no?

Pam: $\quad$ Let's go for yes first.

Jack: $\quad$ Okay, for yes, like, say there's something like a technology - [that] brings in only the good air and it lets the bad air out, like a cone that reaches around the world and lets the bad air out into outer space. 


\section{Bad for Environment}

The SEAS Club children shared a wide range of ways in which technologies can be bad for the environment, and specifically for the: air/atmosphere, animals and their habitats, plants/trees, and the physical Earth. Table 6 summarizes the five most frequent responses in pre- and postinterviews.

Table 5: Summary of Pre-Post Interview Responses: Top Five Reasons for How Technology is Bad for The Environment

\begin{tabular}{|c|c|}
\hline $\begin{array}{c}\text { Pre-Interview Order of Reasons } \\
\text { (Percent/\# of 22 Children) }\end{array}$ & $\begin{array}{c}\text { Pre-Interview Order of Reasons } \\
\text { (Percent/\# of 18 Children) }\end{array}$ \\
\hline $\begin{array}{c}\text { Nasty fumes, smoke, or polluted air is bad } \\
\text { for the animals and air. (27\%; 6 children) }\end{array}$ & $\begin{array}{c}\text { Nasty fumes, smoke, or polluted air is bad } \\
\text { for the animals and air. (33\%; 6 children) }\end{array}$ \\
\hline $\begin{array}{c}\text { Animals' habitats can be destroyed when } \\
\text { technologies replace those habitats. (23\%; } \\
5 \text { children) }\end{array}$ & $\begin{array}{c}\text { Animals' habitats can be destroyed when } \\
\text { technologies replace those habitats. (22\%; } \\
4 \text { children) }\end{array}$ \\
\hline $\begin{array}{c}\text { Technologies that use animal/plant } \\
\text { materials destroy those animals/plants. } \\
(14 \% ; 3 \text { children) }\end{array}$ & $\begin{array}{c}\text { The ground and water can be polluted by } \\
\text { technologies. (17\%; } 3 \text { children) }\end{array}$ \\
\hline $\begin{array}{c}\text { Technology litters the environment. } \\
\text { (14\%; } 3 \text { children) }\end{array}$ & $\begin{array}{c}\text { Technologies that use animal/plant } \\
\text { materials destroy those animals/plants. } \\
\text { (11\%; } 2 \text { children) }\end{array}$ \\
\hline $\begin{array}{c}\text { Animals can be electrocuted. (9\%; } \\
\text { children) }\end{array}$ & $\begin{array}{c}\text { Animals can be physically injured by } \\
\text { technologies. (6\%; } 1 \text { child) }\end{array}$ \\
& $\begin{array}{c}\text { Technology can take away oxygen. (6\%; } \\
1 \text { child) }\end{array}$ \\
\hline
\end{tabular}

Children mentioned different forms of pollution in interviews. Most frequently, they described air pollution in terms of smoke, fumes, or gas that enters the air, which also negatively impacted people (see prior section, Bad for People). Ground and water pollution were mentioned by three children in the post-interview. For example, Connor mentioned that if paper "goes underground sometimes ... it could make the soil not be really good". Toying with the idea that gasoline might be a technology, Andrew discussed the negative consequences of a gas spill:

Pam: $\quad$... Are there any ways that technology might be bad for the environment? Andrew: The only thing I could think of is - there's this movie we saw ... where a tank, like a gas tank spilled. ... and then it made - like a stench that was like, killing the forests. That's the only thing. I don't know, like gas, I don't know if that's technology. 
Another form of pollution exclusively mentioned in the pre-interviews was littering. In two of the three cases, children shared that subways may be bad for the environment because people frequently litter in subways.

Technology was also perceived as potentially taking away things that are important to the environment, namely: animal habitats, the physical Earth (by digging into it to construct buildings), and oxygen (due to the removal of plants that would otherwise produce oxygen). Most often, children mentioned the negative consequences of removing animals' habitats when factories, houses, and subways were built. For example:

Pam: $\quad$... Is it [technology] good for the environment? For animals or the planet?

Donovan: No, not all of them.

Pam: Why?

Donovan: Because it - it kills some of the animals' homes.

Pam: $\quad$ How does it kill animals' homes?

Donovan: Because they build houses where they live.

Perhaps it is not surprising that children so frequently mentioned animal habitats since the $1^{\text {st }}$ grade county curriculum includes a unit on animals. (All children in the SEAS Club attended schools in this pubic system.)

Children also mentioned ways in which technologies could destroy or otherwise harm animals or plants. Animals may experience electrocution on power lines, unknowingly eat a dangerous technology, or have other unfortunate encounters with technology (e.g., being run over by a train). More frequently mentioned than these examples were cases in which animal or plant materials were used to create technologies, which destroyed the animal or plant.

One example that was discussed during the older SEAS Club was how toothbrushes used to be made from sticks with splayed ends. Recalling this in his post-interview, Jack worried that this could result in trees being cut down; he also mentioned trees are cut down to make paper. He worried that this would reduce oxygen from the air that we need to breathe. In the pre-interview, Donovan shared that hunters might kill zebras to make coats, and Chanelle-in describing her design of a backpack for her artwork in another part of the pre-interview-shared that wood would be a better material than leather since using leather is "technically using alligator skin or snake skin."

Finally, one child in post-interview mentioned that technology is bad for the environment because it is not useful to animals. This seemingly naïve point by one young child demonstrates a sophisticated idea: to think about whose problem technology is solving (or not).

\section{The Widget Questions}

\section{Is this a good or a bad widget?}

Children were presented with a widget, and asked: Is this a good or a bad widget? Table 7 is a summary of students' responses. The pre-interview was the first time the children had seen the 
widget, so it was not surprising that about a third responded with something like what Aryonna said: "I don't know. I don't know what this is - I've never seen one of these." Fewer responded this way in the post-interview.

Table 7: Summary of Pre-Post Interview Responses: Answer to "Is this a Good Widget, or a Bad Widget?'”

\begin{tabular}{|c|c|c|}
\hline Answer & $\begin{array}{l}\text { Pre-Interview } \\
\qquad(\mathrm{N}=22)\end{array}$ & $\begin{array}{l}\text { Post-Interview } \\
\qquad(\mathrm{N}=18)\end{array}$ \\
\hline $\begin{array}{l}\text { I have no idea, since I don't know about } \\
\text { widgets. }\end{array}$ & $\begin{array}{c}36 \% \\
\text { (8 children) }\end{array}$ & $\begin{array}{c}11 \% \\
\text { (2 children) }\end{array}$ \\
\hline Good widget; reason provided. & $\begin{array}{l}45 \% \\
\text { (10 children) }\end{array}$ & $\begin{array}{c}44 \% \\
\text { (8 children) }\end{array}$ \\
\hline Good widget; not sure why. & $\begin{array}{l}5 \% \\
(1 \text { child })\end{array}$ & $0 \%$ \\
\hline Partially good, partially bad. & $\begin{array}{c}9 \% \\
\text { (2 children) }\end{array}$ & $\begin{array}{c}11 \% \\
(2 \text { children })\end{array}$ \\
\hline Bad widget; reason provided. & $\begin{array}{c}9 \% \\
\text { (2 children) }\end{array}$ & $\begin{array}{c}28 \% \\
\text { (5 children) }\end{array}$ \\
\hline Bad widget; not sure why. & $0 \%$ & $\begin{array}{c}6 \% \\
\text { (1 child) }\end{array}$ \\
\hline
\end{tabular}

Largely, children articulated ways in which the widget was or could be good. Reasons provided in the pre-interview included: 1) it looked like something their dad or someone else would use to build or fix something ( 3 children); 2) it "looks good" or is free of rust (4 children); 3 ) it does not appear to be able to hurt people ( 1 child); 4) its materials are not from plants or animals, so it is not bad; and 5) it is made by the USA, as evident by the "U.S.A." stamp.

The lattermost point about the USA was not a part of any conversations regarding whether technology was good or bad for people or the environment. Cady articulated her reasoning about why the USA stamp added value to the widget in the following exchange:

Pam: $\quad$ Is it a good widget or a bad widget?

Cady: Oh, it's good because it says the USA.

Pam: $\quad$ It's good because it says USA?

Cady: $\quad$ Mmm hmm (yes).

Pam: $\quad$ Do you think that - so what does it mean when it says USA on it?

Cady: It means like the Army can use it, and it's kind of like a bomb or something.

Pam: $\quad$ You said it's kind of like a bomb or something? And the Army can use it?

Cady: $\quad$ Mmm hmm (yes). 
Pam: $\quad$ And that makes it a good thing? And why is it good?

Cady: $\quad$ Because the Army can use it. And - and do and other people can do it when they're - when some - police can use it.

Later, Cady shared that her friend's dad work for the Army (employing many citizens in the area), and that her father used to be a marine. Although Cady did not mention the USA in the post-interview, another child used the USA stamp as evidence that the widget was good:

Pam: Is that a good widget or a bad widget?

Antonio: $\quad$ A good widget.

Pam: $\quad$ It's a good widget. How do you know?

Antonio: $\quad$ Because it says USA.

Pam: Oh. Because it says USA. Why does USA make it good?

Antonio: $\quad$ Because USA is part of America.

Pam: $\quad$ Part of America? And do Americans make good things?

Antonio: Some.

Later in the interview, Javier wondered if "some of the Army people" use the widget. Other reasons that the widget was deemed good in the post-interviews were similar to those shared in the pre-interview.

Fewer students provided reasons as to why the widget might be bad, and most of those in both pre- and post-interviews had to do with the somewhat loose or "wiggly" nature of the widget (e.g., Julie mentioned "things are not going together like they're supposed to"). Others mentioned that the widget might pinch fingers, hurt babies or animals, or damage other mechanisms, or that it was bad because it was not on something.

\section{What Questions Would You Ask to Find out if the Widget is Good or Bad?}

The SEAS Club children generated many questions in response to the questions: 1) What questions would you ask about this widget if you met someone who knows about the widget?; and 2) What questions would you ask to find out if it was a good or bad widget for people or the environment? The pre- and post-questions were subcoded and grouped, and the frequency of these grouped questions is reflected in Table 8.

The first category in Table 8 reflects the tendency of about one third of the children to have difficulty with the abstract nature of the second question, in particular. For example, Steven responded to this question in a post-interview by saying: "all I could probably say is probably, like, 'sir, do you know if this is a good widget?",

In both the pre- and post-interviews, the most popular questions were about the operation and design of the widget. Children wanted to know what it was, what it did, and how it worked (i.e., its operation). They wanted to know how it was made and the material of which it was made (i.e., its design). Their curiosity about the material was for many, an attempt to decide if the widget was good or bad for the environment. For example, Billy thought that if it was metal, as he suspected, that would not be good for the environment, while Jack said that if it were made of 
wood - which he did not believe it was - it could be bad for the environment as it would be using up natural materials.

Table 8: Frequency of Widget Question Categories in Pre- and Post-Interviews

\begin{tabular}{|c|c|c|c|}
\hline Category & Example Questions & $\begin{array}{l}\text { Pre-Interview } \\
\qquad(\mathrm{N}=22)\end{array}$ & $\begin{array}{l}\text { Post-Interview } \\
\qquad(\mathrm{N}=18)\end{array}$ \\
\hline Direct & $\begin{array}{l}\text { Is it good or bad? } \\
\text { Is it bad for the environment? }\end{array}$ & $\begin{array}{c}32 \% \\
\text { (7 children) }\end{array}$ & $\begin{array}{c}29 \% \\
\text { (5 children) }\end{array}$ \\
\hline Operation & $\begin{array}{l}\text { How does it work? } \\
\text { What does it do? }\end{array}$ & $\begin{array}{c}73 \% \\
\text { (16 children) }\end{array}$ & $\begin{array}{c}53 \% \\
\text { (9 children) }\end{array}$ \\
\hline Design & $\begin{array}{l}\text { How was it made? } \\
\text { What materials was it made of? }\end{array}$ & $\begin{array}{c}64 \% \\
\text { (14 children) }\end{array}$ & $\begin{array}{c}76 \% \\
\text { (13 children) }\end{array}$ \\
\hline Danger & $\begin{array}{l}\text { Should you keep it away from } \\
\text { babies or children? } \\
\text { Does it harm animals? }\end{array}$ & $\begin{array}{c}36 \% \\
\text { (8 children) }\end{array}$ & $\begin{array}{c}29 \% \\
\text { (5 children) }\end{array}$ \\
\hline System & $\begin{array}{l}\text { Is it a part of something else? } \\
\text { Does it run on electricity or batteries } \\
\text { or use oil? }\end{array}$ & $\begin{array}{c}32 \% \\
\text { (7 children) }\end{array}$ & $\begin{array}{c}29 \% \\
\text { (5 children) }\end{array}$ \\
\hline Purpose & $\begin{array}{l}\text { Why do you use it? } \\
\text { What does it do for people? }\end{array}$ & $\begin{array}{c}27 \% \\
\text { (6 children) }\end{array}$ & $\begin{array}{c}18 \% \\
\text { (3 children) }\end{array}$ \\
\hline $\begin{array}{l}\text { Environmental } \\
\text { Impact }\end{array}$ & $\begin{array}{l}\text { Will it destroy animal habitats? } \\
\text { Do animals have to be killed to } \\
\text { use/make this? }\end{array}$ & $\begin{array}{c}9 \% \\
\text { (2 children) }\end{array}$ & $\begin{array}{c}18 \% \\
\text { (3 children) }\end{array}$ \\
\hline Maintenance & $\begin{array}{l}\text { Do you need to get new pieces for } \\
\text { it? } \\
\text { How do you fix this? }\end{array}$ & $\begin{array}{c}9 \% \\
(2 \text { children })\end{array}$ & $\begin{array}{c}6 \% \\
(1 \text { child })\end{array}$ \\
\hline Affiliations & $\begin{array}{l}\text { Why does it say USA? } \\
\text { What are the numbers for? }\end{array}$ & $\begin{array}{c}9 \% \\
\text { (2 children) }\end{array}$ & $0 \%$ \\
\hline Quality & Is it supposed to be loose? & $\begin{array}{c}5 \% \\
(1 \text { child })\end{array}$ & $\begin{array}{c}12 \% \\
\text { ( } 2 \text { children) }\end{array}$ \\
\hline $\begin{array}{l}\text { Testing \& } \\
\text { Effects }\end{array}$ & $\begin{array}{l}\text { When you used it, did you see any } \\
\text { difference in the environment? } \\
\text { Has it ever been tested? }\end{array}$ & $\begin{array}{c}5 \% \\
(1 \text { child })\end{array}$ & $\begin{array}{c}12 \% \\
\text { ( } 2 \text { children) }\end{array}$ \\
\hline Ethics & $\begin{array}{l}\text { Did someone have to steal } \\
\text { something to make this? }\end{array}$ & $0 \%$ & $\begin{array}{c}6 \% \\
\text { (1 child) }\end{array}$ \\
\hline
\end{tabular}


An interesting question posed by one child about design was: Was it made carefully? This question arose from an impromptu lesson in the younger SEAS Club group that resulted when toy cars that were purchased for testing the model bridges began breaking. I asked the children to sort the cars into to piles: Good and Bad. We discussed why it was that so many brand-new toys could be broken before we even had a chance to use them.
Pam: $\quad$ So, if I was the engineer who designed that widget, what would you ask me to find out if it was a good or a bad widget?
Julie: $\quad$ I would ask you if you took a lot of care / making it. Like, remember those cars that weren't very taken care of because some of them wouldn't zoom?
Pam: $\quad$ Yeah. Remember how we found out a whole bunch of them that did not work?
Julie: $\quad$ Yeah and we did the good ones and the bad.
Pam: $\quad$ Yeah?
Julie: $\quad$ Which was a pretty good idea.

A matter of great concern for the children was whether the widget was dangerous to people or animals. Cady, who had noticed the USA stamp on the widget, wanted to know if it was capable of exploding. Three children were concerned that animals may be harmed by the widget, two of whom wondered if animals would unknowingly eat the widget and fall ill.

Children also frequently asked questions regarding what larger system the widget fit into to help them decide if the widget was good or bad for the environment. If it was part of a car or used electricity, some said, then it would be bad since cars pollute the environment. The purpose of the widget was a matter of concern for others. Cast in the technology-helps-people framework, some children wanted to how it helped.

As in the previous section about whether or not the technologies listed on the assessment were good or bad for the environment, questions regarding environmental impact-most especially habitat and the use of animal and plant materials to make the widget-were raised.

The differences between pre- and post-interviews for the widget questions were relatively subtle, as indicated by the percentages in Table 8 . One category that was not present until the postinterview, motivated by two students, was a question about the effects of the widget and the degree to which it had been tested. Fredrick wanted to know the following: "What happened to you when you got that widget?"; and "When you used it, did you see any difference in the environment?" Zachary offered: "I would ask you if anybody ever tried it. Because if they would have gotten hurt, then you should have told me."

\section{Discussion}

This paper has aimed to use qualitative data to further elaborate children's thinking about what constitutes technology, and about the potential and realized benefits and detriments of technology. Despite the many attendance challenges in the SEAS Club, the children collectively moved away from more naïve definitions of technology and towards more sophisticated understandings. The range in the development of the children's ideas is reflected in the cases of 
Amelia, Cady, Daniel, and Zachary, all at different points along the journey towards more robust-but not overly exclusive-conceptions of technology.

The critical analysis that the children employed in response to questions about the benefits and detriments of technologies - be they on the assessments, in their own conceptions and examples of technologies at the end of the club, or in the form of a widget-revealed that these children, both before and after the SEAS Club are able to think critically to some extent about technology. Their critical analyses are, not surprisingly, shaped by what they consider technology to be, and thus after participating in the SEAS Club, the downsides of technology become more robust than the brain-rotting tendencies of too much television, and include other kinds of technologies with other potentially negative ramifications for people or the environment. Some have begun to see that technologies can affect our environment in positive ways. However, overall, the children largely see technology as having more benefits than downsides for people, and more downsides than benefits for the environment.

There was a range in the degree to which children took on critical analysis, with some stifled by the complex task of thinking about what else to ask a widget expert besides "Is this widget good or bad?" to get at the answer to that very question. Others presented question after question, or presented a balanced analysis of the good and bad qualities of the widget or other technologies.

In the theoretical background of the paper, the following critical questions about technology were posed:

- How does this technology position me, others, or reality?

- Does this technology include or ignore my or others' voice(s)?

- In whose interests has this technology been designed?

In differing ways, SEAS Club children addressed each of these. They, for example,: questioned why a technology could be considered good for an animal if the animal was not helped by it; asked about the purpose of the widget-how did it help people?; wondered if children or babies would be hurt by a widget that would be safe for adults; thought about asking why they would be asked to use a widget if someone else knew it was harmful; were frustrated at the thought of a widget that constantly needed fixing or replacement parts; and implicitly questioned whether the animal's voices — and their habitats and bodies - were a part of the conversation regarding the use, design, and construction of technology.

This paper describes a pilot study. There is much more to be learned about how children think critically about technology, what instructional methods can be developed to encourage critical thinking, and what set of concrete examples might be used in instruction to help children see the ways in which a broad spectrum technologies can be both helpful and harmful to people and the larger environment. 


\section{Acknowledgments}

This project was generously funded by a grant from the Faculty Development Research Community at Towson University. The author would like to thank the staff at the BGC, the children who participated in the SEAS Club, and the SEAS Club parents for their support.

References

1. ITEA (2000). Standards for technological literacy: Content for the study of technology. Reston, VA: Author.

2. $\quad$ NRC (1996). National Science Education Standards. Washington, D.C.: National Academy Press.

3. $\quad$ AAAS (1989). Science for all Americans. New York: Oxford University Press.

4. Rose, M. A. (2007). Perceptions of technological literacy among science, technology, engineering, and mathematics leaders. Journal of Technology Education, 19(1), 35-52.

5. Cunningham, C. M., Lachapelle, C. P., \& Lindgren-Streicher, A. (2005). Assessing elementary school students' conceptions of engineering and technology. Proceedings of the 2005 American Society for Engineering Education Annual Conference \& Exposition.

6. Cajas, F. (2001). The science/technology interaction: Implications for science literacy. Journal of Research in Science Teaching, 38(7), 715-729.

7. Lachapelle, C. P., \& Cunningham, C. M. (2007). Engineering is Elementary: Children's changing understandings of science and engineering. Proceedings of the 2007 American Society for Engineering Education Annual Conference \& Exposition.

8. Beneson, G. (2001). The unrealized potentital of everyday technology as a context for learning. Journal of Research in Science Teaching, 38(7), 730-745.

9. $\quad$ EiE (2007). Preparatory lesson: What are engineering and technology? Catching the wind: Designing windmills. Boston, MA: Museum of Science, National Center for Technology Literacy.

10. Solomon, J., \& Aikenhead, G. (Eds.). (1994). STS Education: International perspectives on reform. New York: Teachers College Press.

11. Luke, A. (2000). Critical literacy in Australia: A matter of context and standpoint. Journal of Adolescent and Adult Literacy, 43(5), 448-461.

12. Freebody, P., \& Luke, A. (1990). "Literacies" programs: Debates and demands in cultural context. Prospect: The Australian Journal of TESOL, 5(5), 7-16.

13. O'Brien, J. (1994). Show Mum you love her: Taking a new look at junk mail. Reading, 28(1), 43-46.

14. Moje, E. B., Dillon, D. R., \& O'Brien, D. (2000). Reexamining roles of learner, text, and context in secondary literacy. Journal of Educational Research, 93(3), 165-180.

15. Fairclough, N. (1992). Intertexuality in critical discourse analysis. Linguistics and Education, 4(3-4), 269293.

16. Bull, G., \& Anstey, M. (2007). Exploring visual literacy through a range of texts. Practically Primary, 12(3), 4-7.

17. Brickhouse, N. W., \& Lottero-Perdue, P. S. (2007). Constructing critical science and social identities in a girls' and a boys' summer science book club. In W.-M. Roth \& K. Tobin (Eds.), Science, learning, and identity: Sociocultural and cultural-historical perspectives. Rotterdam, The Netherlands: Sense Publishers.

18. Lottero-Perdue, P. S. (2005). Critical science-related text analysis in a breastfeeding information, support, and advocacy community of practice. Unpublished Dissertation. University of Delaware.

19. Winner, L. (1986). The whale and the reactor. Chicago: University of Chicago Press.

20. Bunting, E., \& Payne, C. F. (2006). Pop's bridge. New York: Harcourt, Inc.

21. Mann, E. (1996). The Brooklyn Bridge. New York: Mikaya Press.

22. Walker, N. (2007). Generating wind power. New York: Crabtree Publishing Company.

23. Spradley, J. (1967). The ethnographic interview. New York: Holt, Rinehart \& Winston.

24. Glaser, B., \& Strauss, A. (1967). The discovery of grounded theory. Hawthorne, NY: Aldine. 
25. Charmaz, K. (2000). Grounded theory: Objectivist and constructivist methods. In N. K. Denzin \& Y. S. Lincoln (Eds.), Handbook of qualitative research (2nd ed., pp. 509-536). Thousand Oaks, CA: Sage.

${ }^{\mathrm{i}}$ Other texts were selected to encourage children to consider that girls/women can do engineering, too. This will be a focus of an upcoming paper.

ii This was extremely disappointing, as one intent of the SEAS Club was to reach out to a diverse group of children. iii In three cases, the author or other assistant proctors helped children write responses to the "How do you know if something is technology?" question. These children had great difficulty with writing, and spoke their answers to the author/proctors, who transcribed the answers on the assessments. No assistant proctors were available to do this for the post assessment.

iv More accurately, the environment includes people, the earth, atmosphere, other animals, etc. The simple environment/people dichotomy used in these interviews was employed to separate self from outside-of-self, but is certainly subject to critique. 